\title{
Long Non-Coding RNAs as Emerging Regulators of Pathogen Response in Plants
}

\author{
Yashraaj Sharma ${ }^{1,2}{ }^{(0)}$, Alok Sharma ${ }^{1}\left(\mathbb{D}\right.$, Madhu $^{1}\left(\mathbb{D}\right.$, Shumayla $^{1}$, Kashmir Singh ${ }^{2}(\mathbb{D}$ \\ and Santosh Kumar Upadhyay $1, * \mathbb{B}$
}

1 Department of Botany, Panjab University, Chandigarh 160014, India; yashraajsharma1@gmail.com (Y.S.); sharmaalok0001@gmail.com (A.S.); mds.3333stu@gmail.com (M.); shumaylasaifi5@gmail.com (S.)

2 Department of Biotechnology, Panjab University, Chandigarh 160014, India; kashmirbio@pu.ac.in

* Correspondence: skupadhyay@pu.ac.in; Tel.: +91-172-2534001; Fax: +91-172-2779510

check for updates

Citation: Sharma, Y.; Sharma, A.; Madhu; Shumayla; Singh, K.; Upadhyay, S.K. Long Non-Coding RNAs as Emerging Regulators of Pathogen Response in Plants. Non-coding RNA 2022, 8, 4. https:/ / doi.org/10.3390/ncrna8010004

Academic Editor: Luca Falzone

Received: 28 December 2021

Accepted: 8 January 2022

Published: 11 January 2022

Publisher's Note: MDPI stays neutral with regard to jurisdictional claims in published maps and institutional affiliations.

Copyright: (C) 2022 by the authors. Licensee MDPI, Basel, Switzerland. This article is an open access article distributed under the terms and conditions of the Creative Commons Attribution (CC BY) license (https:// creativecommons.org/licenses/by/ $4.0 /)$.

\begin{abstract}
Long non-coding RNAs (lncRNAs) are transcripts without protein-coding potential that contain more than 200 nucleotides that play important roles in plant survival in response to different stresses. They interact with molecules such as DNA, RNA, and protein, and play roles in the regulation of chromatin remodeling, RNA metabolism, and protein modification activities. These lncRNAs regulate the expression of their downstream targets through epigenetic changes, at the level of transcription and post-transcription. Emerging information from computational biology and functional characterization of some of them has revealed their diverse mechanisms of action and possible roles in biological processes such as flowering time, reproductive organ development, as well as biotic and abiotic stress responses. In this review, we have mainly focused on the role of lncRNAs in biotic stress response due to the limited availability of knowledge in this domain. We have discussed the available molecular mechanisms of certain known lncRNAs against specific pathogens. Further, considering that fungal, viral, and bacterial diseases are major factors in the global food crisis, we have highlighted the importance of lncRNAs against pathogen responses and the progress in plant research to develop a better understanding of their functions and molecular mechanisms.
\end{abstract}

Keywords: abiotic stress; biotic stress; fungal; lncRNAs; plant development; viral

\section{Introduction}

Enhanced knowledge of the involvement of non-protein-coding regions of DNA in regulatory functions has provided remarkable progress in elucidating the important roles of non-coding molecules. The non-coding regions of the genome are not involved in any protein coding. The main focus on the protein-coding region of DNA delayed the discovery and the functional elucidation of the non-protein-coding regions of DNA and misidentified it as a "junk DNA" [1]. The non-coding regions of DNA are transcribed into a large number of transcriptional units known as non-coding RNAs (ncRNAs). These ncRNAs were initially considered to be trash DNA, but recently, they have become a key component of various regulatory processes [2]. High-throughput sequencing and expression profiling have given the limelight to these transcriptional units after decades of existential crisis [3].

Non-coding RNAs can be classified into two broad categories: housekeeping and regulatory ncRNAs. Structural ncRNAs such as tRNA, rRNA, snRNA, and snoRNA are grouped into housekeeping ncRNAs and are constitutively expressing in the cell [4]. Based on their length, small RNAs (sRNAs such as miRNA, siRNA, and piRNA) and IncRNAs are various types of regulatory ncRNAs. Earlier, researchers had emphasized the key role of sRNA in the regulation of gene expression at the transcriptional and posttranscriptional level and considered lncRNAs to be "transcriptional noise". However, recent studies on model plants have revealed several important roles of lncRNA in various plant development processes, for instance, regulation of photomorphogenesis by red light, 
flowering, and biotic and abiotic stress responses [5-9]. The first eukaryotic IncRNA was H19, identified in the mouse [10]. GmENOD90 from Glycine max was the first identified plant lncRNA using RNA sequencing and in vitro based analysis [11]. Due to high-resolution transcriptomic analysis, the identification of lncRNAs in plants has blossomed and caught up with the mammalian research field in a few years [11]. Long non-coding RNAs are transcribed by RNA polymerase II, similarly to mRNAs, and processed through $5^{\prime}$-capping and $3^{\prime}$ poly (A) addition. In addition to RNA Pol II, they are also transcribed by polymerase IV/V in plants [12,13] and processed through splicing or non-splicing and polyadenylation or non-polyadenylation. Long non-coding RNAs can be broadly classified on the basis of their genomic location as: (i) long intergenic ncRNAs (lincRNAs), (ii) long intronic ncRNAs (incRNAs), and (iii) natural antisense transcripts (NATs) [14]. Their subcellular localization can be nuclear or cytoplasmic. The lincRNAs and incRNAs are transcribed from intergenic and intronic regions of DNA, respectively, while NATs originate from associated genes of complementary DNA strands [15]. Apart from the above groups, there is one more group of lncRNA, which are less in abundance and are transcribed from back-spliced exons, known as circular non-coding RNAs (circRNAs). Some lncRNAs are transcribed by RNA polymerase II from regions of essential DNA elements such as promoter and enhancer, for instance, PROMPT and eRNAs. These RNAs are short lived with rapid turnover rates and targeted by the RNA exosome in the nucleus, indicating their significance in gene regulation [16]. The ideally known function of lncRNAs might be in the regulation of transcription as "riboregulators." Moreover, the molecular mechanism of lncRNAs can be depicted in several ways; they can act as signals and decoys of miRNAs or a competitor of pre-mRNAs in alternate splicing, as a guide in directing RNP (ribonucleoprotein) complex to specific targets, and as scaffolds in the recruitment of complex protein molecules [17].

\section{Origin and Database Development of Plant lncRNAs}

The mechanisms of plant adaptation to different stresses that we see today are the result of a joint venture among plants, microorganisms, and different types of environmental conditions. Plants have encountered various biotic and abiotic stresses during the long course of evolution and these interactions have been recorded in the form of intricate molecular mechanisms. These mechanisms developed over time and help in many developmental processes by surviving and sustaining harsh conditions such as mechanical and biological stresses. A genome's transcriptional inventory consists of coding as well as non-coding RNAs, and the latter is said to be equally contributing to the plant's complex adaptations processes. Non-coding RNAs (ncRNAs) have emerged as crucial bioactive molecules that contribute to genome and phenotypic diversity. Only around $2 \%$ out of $90 \%$ of the transcribed RNAs from the eukaryotic genome result in the production of proteins [18,19]. Next-generation sequencing (NGS) technology advancements have been critical to finding ncRNAs in plants, in combination with homology-based and/or experimental techniques $[20,21]$. High-throughput sequencing has made major advances in understanding the biology of lncRNAs. Plant lncRNAs remain a mystery, despite new findings that provide insight on their functions and methods of action. Moreover, the origins and roles of these ncRNAs have been reported to be diverse [22]. Existing transposable elements (TEs), random hairpin configurations, pseudogenization of protein-coding sequence, and DNA repeat are some prominent explanations for the origins of various ncRNAs such as miRNA, siRNA, piRNA, and lncRNA [23-26].

Despite being poorly conserved, sequence conservation among subsets of lncRNAs across the species can be found [27]. On exploring biological significance and evolution across 23 plant species, low sequence conservation at the transcript level among the majority of lncRNAs has been observed [28]. Conservation studies of lncRNAs to predict their possible functions are difficult because of less availability of tools and datasets. However, some databases have been developed recently and are made available to researchers to decipher their phylogenetic relationship, expression pattern, and molecular interactions. Plant specific databases such as PlncRNAdb, PLncDB 2.0, CANTATAdb 2.0, GreeNC, 
TAIR10, PNRD, and PlantNATsDB, along with databases containing information from the plant as well as other organisms (e.g., RNA central, EVLncRNAs, lncRNAdbv2.0, and NONCODE v4) are available to make more in-depth inferences on the lncRNAs [29]. Some of the databases with their features for the identification of plant lncRNAs have been listed in the table below (Table 1).

Table 1. Some databases available for the identification of plant lncRNAs.

\begin{tabular}{|c|c|c|}
\hline Database & Features & Reference \\
\hline $\begin{array}{l}\text { Plant long non-coding } \\
\text { RNA database }\end{array}$ & $\begin{array}{l}\text { This database consists of }>13,000 \\
\text { lincRNAs and associated epigenetic markers }\end{array}$ & {$[18]$} \\
\hline Plant ncRNA database & $\begin{array}{l}\text { It consists of } 11 \text { different types of ncRNAs of } \\
150 \text { plant species }\end{array}$ & {$[30]$} \\
\hline Green non-coding database & $\begin{array}{l}\text { It consists of data of } 37 \text { plant species and algae with } \\
\text { more than } 120,000 \text { lncRNAs }\end{array}$ & {$[31]$} \\
\hline $\begin{array}{l}\text { The Arabidopsis } \\
\text { information resource }\end{array}$ & It also consists of data of various noncoding RNAs & {$[32]$} \\
\hline Araportll & $\begin{array}{c}\text { It consists of annotated lincRNA, NATs, and various } \\
\text { other ncRNAs }\end{array}$ & {$[33]$} \\
\hline $\begin{array}{l}\text { Plant natural antisense } \\
\text { transcripts database }\end{array}$ & $\begin{array}{l}\text { It consists of NATs annotated data along with } \\
\text { expression of small RNA of } 70 \text { plant species }\end{array}$ & {$[34]$} \\
\hline CANTATAdb & $\begin{array}{l}\text { It consists of data of } 45,000 \text { lncRNAs of } 10 \text { model } \\
\text { plant species }\end{array}$ & {$[35]$} \\
\hline
\end{tabular}

\section{Involvement of lncRNAs in Various Biological Processes}

Long non-coding RNAs control the gene regulation processes mostly at the level of mRNA processing, editing, and turnover [36]. However, some lncRNAs also display gene regulatory functions by post-transcriptional modifications. They mediate regulatory functions by binding to DNA/RNA either through cis-acting or trans-acting sequences. Various lncRNAs have been identified in plants coupled with the defense responses related to plant immunity and adaptation to environmental conditions. Many lncRNAs have been documented using in silico analysis, whole-genome and RNA sequencing in different plants such as Arabidopsis thaliana [37], Triticum aestivum [38], Oryza sativa [39], Zea mays [40], Medicago truncatula [41], Vitis vinfera [42], etc. Ample reports have been published on the possible functions and molecular mechanism of lncRNAs despite being less explored and functionally characterized [43]. Their mode of action and targeting mechanism differ in different biological processes. Most of the reported lncRNAs are stress responsive [44]. However, their roles have also been reported in other plant development processes (Figure 1). The lncRNAs involved in the regulation of flowering time are the most diverse studied group of lncRNAs in model plants. FLOWERING LOCUS C (FLC), a key regulator of flowering time in Arabidopsis is epigenetically regulated by $\ln$ CRNAs COLD INDUCED LONG ANTISENSE INTRAGENIC RNAs (COOLAIR) and COLD-ASSISTED INTRONIC NON-CODING RNA (COLDAIR) $[20,45,46]$. COOLAIR and COLDAIR help in recruiting PHD-PRC2 complex enabling histone modification of FLC. Some lncRNAs such as EARLY NODULIN 40 (ENOD40) and AUXIN REGULATED PROMOTER LOOP (APOLO) are involved in nodule development and polar auxin transport, respectively. ENOD40 participates in the nodule development in the leguminous plants by relocalization of RNA binding protein 1 (RNP1) from nuclear speckles to cytoplasmic granules [47]. APOLO, an intergenic lncRNA, is transcribed by RNA polymerase II and V, this dual APOLO transcription directs the chromatin loop dynamics modulating the expression of neighbor PID gene that plays an important role in the regulation of polar auxin transport $[48,49]$. Several lncRNAs have been reported to be involved in regulating various kinds of challenges related to abiotic stresses. For instance, under phosphate starvation conditions, a lncRNA Induced by phosphate starvation 1 (IPS1) is expressed in Arabidopsis which promotes 
phosphate uptake and accumulation. It acts as an endogenous target mimic (eTM) for miR399, which is a repressor of PHOSPHATE2 (PHOS2). PHOS2 is responsible for encoding ubiquitin-conjugating (E2) enzymes, and its repression enhances phosphate uptake and accumulation [50]. Some lncRNAs are responsive to light such as HIDDEN TREASURE 1 (HID1). It negatively regulates the expression of the PHYTOCHROME-INTERACTING FACTOR (PIF3), a transcription factor that is the main repressor in photomorphogenesis resulting in the hypo-photomorphogenic response under red light conditions [5,51]. Some lncRNAs regulate photoperiod-sensitive genetic male sterility modulating reproductive organ development. The reduced transcript level of long day-specific male fertility-associated RNA ( $L D M A R)$ under long-day conditions causes programmed cell death at the time of anther development in rice leading to male sterility [52,53].

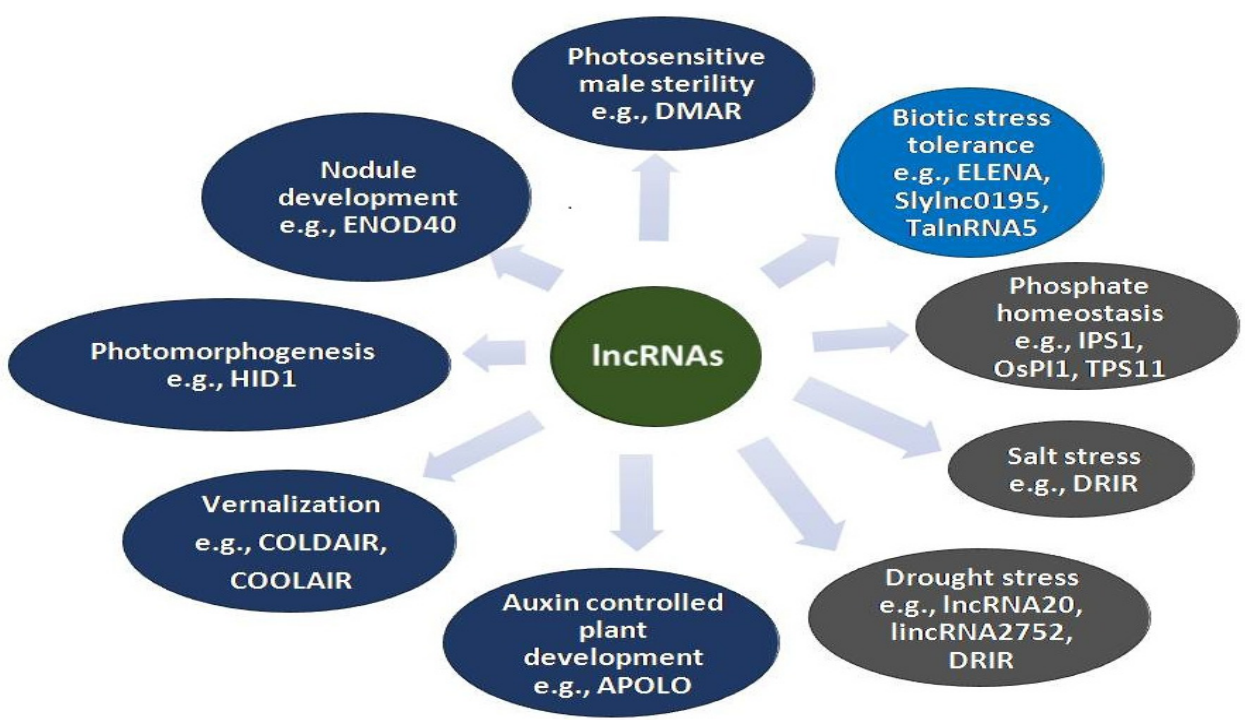

Figure 1. Roles of some of the functionally characterized lncRNAs in different biological processes.

\section{Roles of lncRNAs in Various Biotic Stress Responses}

Plants have evolved through sets of defense mechanisms to mitigate different diseases effectively. Plant cells respond to pathogen attacks after pathogen recognition, triggering downstream signaling networks at the molecular level to arrange transcriptional machinery [54]. A minimal effort has been made in identifying and annotating the lncRNAs related to biotic stresses. Therefore, the molecular mechanisms of some lncRNAs in three major biotic stresses have been highlighted below (Table 2 and Figure 2).

Table 2. Long non-coding RNAs related to the biotic stress response.

\begin{tabular}{|c|c|c|c|c|c|}
\hline Pathogen & Associated Stress & lncRNA & Mechanism & Plant & Reference \\
\hline \multirow{3}{*}{ 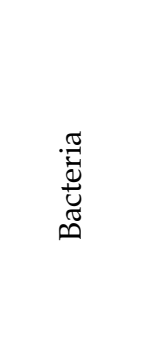 } & $\begin{array}{l}\text { Bacterial speck disease } \\
\text { (Pseudomonas syringae pv. } \\
\text { tomato DC } 3000)\end{array}$ & Up- ELENA1 & $\begin{array}{l}\text { Directly interact } \\
\text { with MED19a }\end{array}$ & Arabidopsis thaliana & [55] \\
\hline & $\begin{array}{l}\text { Bacterial canker (Pseudomonas } \\
\text { syringae pv. actinidiae) }\end{array}$ & $\begin{array}{c}\text { Up- TCONS_00202033, } \\
\text { TCONS_0019494 \& } \\
\text { TCONS_00076221 }\end{array}$ & Unknown & Actinidi adeliciosa & [56] \\
\hline & $\begin{array}{c}\text { Bacterial leaf blight } \\
\text { (Xanthomonas oryzae pv. oryzae) }\end{array}$ & Up- ALEX1 & $\begin{array}{l}\text { Interacts with JA } \\
\text { related genes }\end{array}$ & Oryza sativa & [57] \\
\hline
\end{tabular}


Table 2. Cont.

\begin{tabular}{|c|c|c|c|c|c|}
\hline Pathogen & Associated Stress & $\operatorname{lncRNA}$ & Mechanism & Plant & Reference \\
\hline \multirow{9}{*}{ 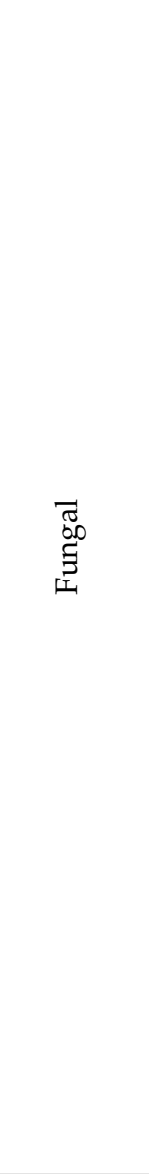 } & $\begin{array}{l}\text { Powdery mildew (Blumeria } \\
\text { graminis f. sp. tritici) }\end{array}$ & $\begin{array}{l}\text { Up- TalnRNA5, } \\
\text { TapmlnRNA19 }\end{array}$ & $\begin{array}{l}\text { Precursor of } \\
\text { miR2004 }\end{array}$ & Triticum aestivum & {$[58]$} \\
\hline & $\begin{array}{l}\text { Powdery mildew (Blumeria } \\
\text { graminis f. sp. tritici) }\end{array}$ & Up- TalnRNA9 & $\begin{array}{c}\text { Signal recognition } \\
\text { particle } 7 S \text { RNA } \\
\text { variant } 1\end{array}$ & Triticum aestivum & {$[58]$} \\
\hline & $\begin{array}{l}\text { Powdery mildew (Blumeria } \\
\text { graminis f. sp. tritici) }\end{array}$ & $\begin{array}{l}\text { Up- TapmlnRNA2, } \\
\text { TapmlnRNA7 }\end{array}$ & $\begin{array}{l}\text { Precursor of } \\
\text { siRNA }\end{array}$ & Triticum aestivum & {$[58]$} \\
\hline & $\begin{array}{c}\text { White mold } \\
\text { (Sclerotinia sclerotiorum) }\end{array}$ & $\begin{array}{c}\text { Up- TCONS_00012499, } \\
\text { TCONS_00004577, } \\
\text { TCONS_00004034, } \\
\text { TCONS_00009614, } \\
\text { TCONS_00015411 }\end{array}$ & Precursor of mi156 & Brassica napus & [59] \\
\hline & $\begin{array}{c}\text { White mold } \\
\text { (Sclerotinia sclerotiorum) }\end{array}$ & $\begin{array}{c}\text { Up- TCONS_00006568, } \\
\text { TCONS_00018692, } \\
\text { TCONS_000017152, } \\
\text { TCONS_00008591, } \\
\text { TCONS_00001092 }\end{array}$ & Precursor of mi169 & Brassica napus & [59] \\
\hline & $\begin{array}{c}\text { Wilt disease } \\
\text { (Fusarium oxysporum) }\end{array}$ & Up- TAR-66 (lincRNA) & $\begin{array}{l}\text { Co-induction with } \\
\text { neighboring } \\
\text { defense-related } \\
\text { gene }\end{array}$ & Arabidopsis thatiana & {$[60]$} \\
\hline & $\begin{array}{c}\text { Wilt disease } \\
\text { (Fusarium oxysporum) }\end{array}$ & $\begin{array}{l}\text { Up- TAR- } 67,-191,- \\
197,-224\end{array}$ & Unknown & Arabidopsis thaliana & {$[60]$} \\
\hline & $\begin{array}{l}\text { Stripe rust (Puccinia striiformis } \\
\text { f. sp. tritici) }\end{array}$ & Up- TalncRNA18, 106 & Unknown & Triticum aestivum & {$[61]$} \\
\hline & $\begin{array}{l}\text { Stripe rust (Puccinia striiformis } \\
\text { f. sp. tritici) }\end{array}$ & $\begin{array}{l}\text { Up \& Dp at different } \\
\text { dpi- TalncRNA73, } 108\end{array}$ & Unknown & Triticum aestivum & {$[61]$} \\
\hline \multirow{3}{*}{$\stackrel{\pi}{7}$} & TYLCV Infection & Up- Slylnc0195 & $\begin{array}{l}\text { Target mimicry of } \\
\text { miR166 }\end{array}$ & $\begin{array}{c}\text { Solanum } \\
\text { lycopersicum }\end{array}$ & [62] \\
\hline & TYLCVInfection & Dn- Slylnc1077 & $\begin{array}{l}\text { Target mimicry of } \\
\text { miR399 }\end{array}$ & $\begin{array}{c}\text { Solanum } \\
\text { lycopersicum }\end{array}$ & [62] \\
\hline & CGMMV infection & Up-lncRNALNC_1497 & $\begin{array}{c}\text { Target mimicry of } \\
\text { MIR4995- } \\
\text { p5_Iss19GC }\end{array}$ & Citrullus lanatus & [63] \\
\hline
\end{tabular}

Up, upregulation; Dn, Downregulation; dpi, days post-inoculation; TAR, transcriptionally active region; TYLCV, tomato yellow leaf curl virus; CGMMV, cucumber green mottle mosaic virus.

\subsection{Long Non-Coding RNAs against Fungal Infection}

Commercially valuable crops such as wheat, rice, tomato, and cotton can be severely damaged by fungal diseases. Powdery mildew (PM) and stripe rust in wheat caused by Blumeria graminis $f$. sp. tritici (Bgt) and Puccinia striiformis f. sp. tritici (Pst), respectively, are such examples. Rice blast is another example of such a destructive disease caused by Magnaporthe oryzae and resulting in remarkable yield loss. The molecular studies of these diseases can provide better insights for developing pathogen resistance strategies.

A comparative expression profile analysis of two cultivars of wheat (PM-susceptible JD8 and PM-resistance JD8-pm30) in response to powdery mildew (PM) infection has revealed expression patterns of 71 lncRNAs in a tissue-specific manner [58]. It was found that some (TapmlnRNA5, TapmlnRNA8, and TapmlnRNA19) differentially expressing lncRNAs in different tissues were precursors of miRNA having stable hairpin structures. The tissue dependent expression of these lncRNAs in response to Bgt infection indicates their role in the development and regulation of biotic stress [58]. 


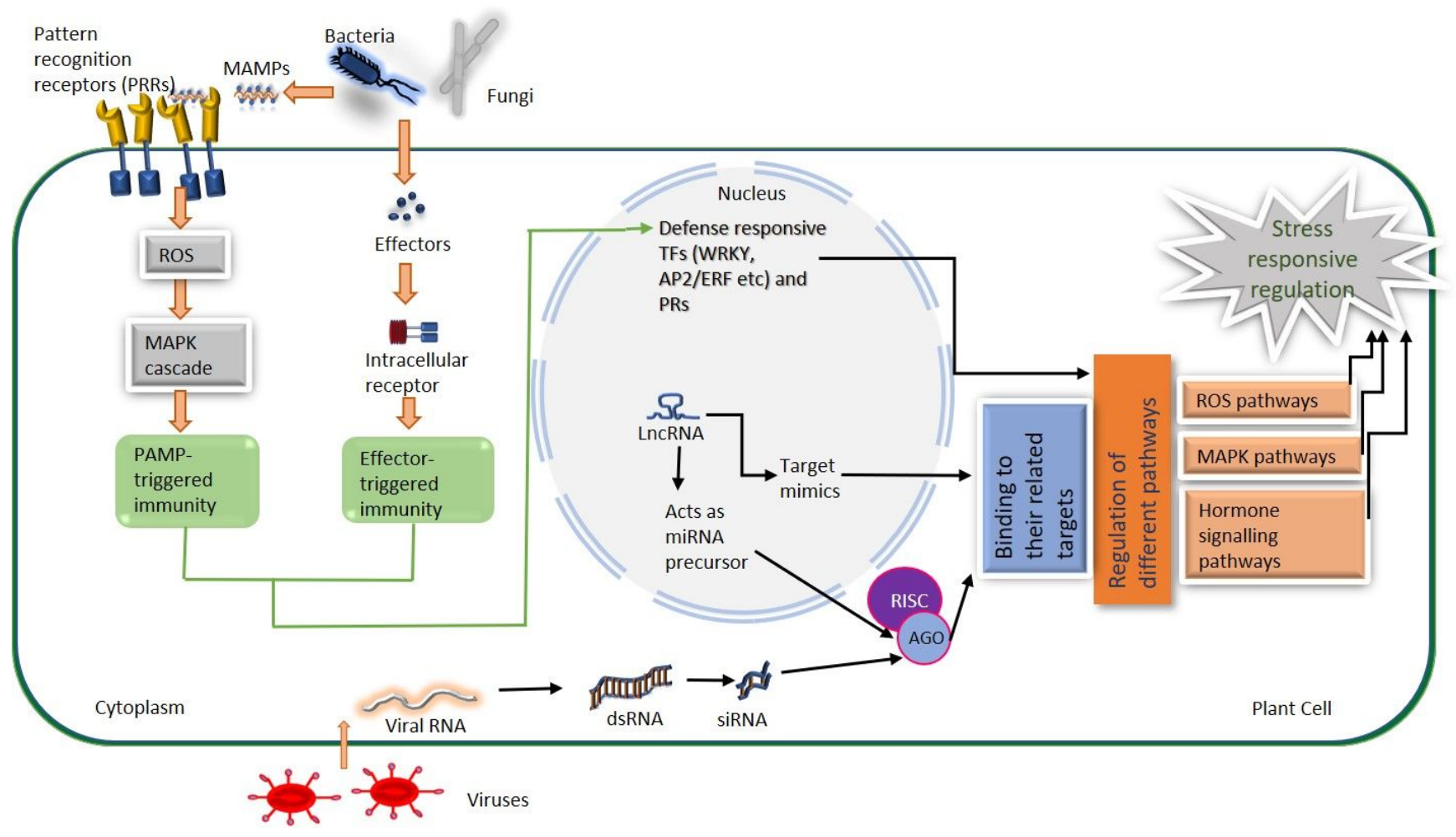

Figure 2. A general model of stress-responsive regulation by regulatory lncRNAs. After stress signal perception, PAMP-triggered immunity (PTI) is activated through the production of signal transducers such as reactive oxygen species (ROS). Pathogen-specific effector-triggered immunity (ETI) is activated by NB-LRR resistance (R) genes after effectors such as the virulence factor of pathogens, enter into the plant cells. PTI and ETI both lead to activation of defense-related pathways. Long non-coding RNAs play important regulatory functions in various plant defense mechanisms either by acting as a precursor of miRNAs and siRNAs or as a miRNA target mimic. (NB-LRR, nucleotide-binding leucine-rich repeats; MAPK, mitogen-activated protein kinase; TFs, transcription factor; RISC, RNA-induced silencing complex; AGO, argonaute proteins). The figure has been adapted and modified from: (1) Taylor \& Francis, Critical Reviews in Bio-technology, 38:1, 93-105, 2018, Emerging roles of long non-coding RNAs in plant response to bio-tic and abiotic stresses by Nejat, N and Mantri, N [54]. Copyright (C 2018 by Taylor \& Francis, License Number: 5237561368073. (2) Springer Nature, Functional \& Integrative Genomics, 21, 313-330, 2021, Regulatory non-coding RNAs: a new frontier in regulation of plant biology by Bhogireddy, S., et al. [64].

By investigating changes in transcriptionally active regions (TARs) (both TARs antisense to overlapping or adjacent genes and intergenic TARs) using a strand-specific RNA-seq approach, 15 lncNATs and 20 lincRNAs were identified in Arabidopsis thaliana against Fusarium oxysporum infection [60]. Functional characterization of some lncRNAs using knockout or knockdown in Arabidopsis plants have revealed evidence of lncRNAs role against disease development. For instance, novel intergenic TAR-191 and TAR-197 induced upon F. oxysporum infection were attenuated in the RNA interference (RNAi) line and T-DNA insertion knockout lines, respectively, and these lines were showing significant disease development [60].

Intriguingly, there was a negative correlation between co-induction of transcripts from the At2g30770 gene and its lncNATs after F. oxysporum infection. The At $2 g 30770$ gene encodes CYP71A13, an essential P450 enzyme involved in the biosynthesis of an essential phytoalexin called camalexin which plays important role in disease resistance. In the core promoter of this gene, TCA-element and TC-rich repeat are found which are responsive to salicylic acid and stresses, respectively, suggesting the presence of shared TFs binding sites and pathogen responsive elements in the promoter regions [60]. 
Phytophthora infestans which is the causal agent of late blight (LB) in tomatoes causes serious economic loss worldwide in field-grown tomatoes and is a major threat to its production. A comparative transcriptomic analysis of resistant $(S p)$ and susceptible tomatoes lines $(S l z)$ against $P$. infestans infection identified a total of 1037 differentially expressed genes (DEGs) and 688 DElncRNAs (DELs) [65]. After analyzing co-localization and expression between DEGs and DELs, lncRNA16397, a lncNAT of the glutaredoxin gene SlGRX22, was identified, which regulates expression of SIGRX22. GRXs are glutathione-dependent disulfide oxidoreductases involved in oxidative stress response in plants [66]. The $\operatorname{lncRNA16397}$ and $S p G R X$ overexpressing plants showed fewere LB symptoms, depicting their roles in disease resistance. SpGRX functions by reducing ROS accumulation and alleviating injury in cell membrane eventually enhancing resistance in tomato against $P$. infestans.

A genome-wide investigation carried out in susceptible Vitis vinifera in response to obligate biotrophic phytopathogens Erysiphe necator and Plasmopara viticola, causing agents of PM and DM (Downey mildew), respectively, identified 71 PM and 83 DM-responsive lncRNAs [67]. A co-expression analysis revealed that 52 PM responsive lncRNAs were co-regulating with 33 protein-coding sequences (CDS) and 22 DM-responsive lncRNAs were found to be co-expressed with 127 CDS. Further, a Gene Ontology (GO) enrichment analysis revealed the functional annotation of these CDS sequences, and highlighted the putative role of the co-expressed lncRNAs in plant defense response against the PM and DM infection [67]. Similar results were also previously found in $V$. vinifera, in response to Botrytis cinerea (grey mold (GM)). A co-expression analysis of 47 GM-responsive lncRNAs and 179 CDS revealed potential interaction between them and the role of lncRNAs in defense response against GM infection [68].

Plants have evolved the innate immune system to counter various harmful pathogens such as fungi. They can respond against a range of pathogens carrying pathogen-associated molecular patterns (PAMPs) and effector molecules [69]. PAMP-triggered immunity (PTI) acts as the first line of plant innate immunity against a pathogen attack. PAMPs are recognized by trans-membranous pattern recognition receptors (PRRs), which trigger a weak immune response called PTI [70,71]. The second line of plant innate immunity is effector-triggered immunity (ETI), which is activated upon the recognition of pathogen molecules called virulence (Avr) effectors [72]. These highly variable effector molecules trigger robust hypersensitive reactions mediated by highly polymorphic plant resistance (R) proteins. The innate immune system of plants, via these two layers, counters a pathogen attack by activating many defense-related genes by various signaling pathways [73-77]. The IncRNAs may alter the expression of those defense-related genes at the transcriptional and post-transcriptional levels to mitigate the pathogens attack. However, their role in adaptation and specificity against pathogens and their interaction with lncRNAs is yet to be deciphered [54]. Transcription factors (TFs) such as NAC, AP2/ERF, WRKY, and C2H2 have been reported to be involved in the regulation of plant response against pathogens. A co-expression analysis of some lncRNAs with these neighboring TFs has suggested a co-regulation relationship with adjacent protein-coding genes, predicting regulatory roles of lncRNAs in both positive and negative ways. Many fungi-responsive lncRNAs have been identified and their functions have been predicted with the help of technologies such as genome-wide microarray analysis and SBS sequencing, supporting the involvement of lncRNAs in the basal defense mechanism of plants. Most of the functional cues of lncRNAs based on bioinformatical analysis have suggested that lncRNAs can potentially interact with other classes of ncRNAs including small non-coding RNAs such as miRNAs $[67,68]$. In addition, techniques such as RNAi and T-DNA insertion have suggested their role by acting as either a precursor of miRNA or miRNA mimics, yet their functional network is to be deciphered.

\subsection{Long Non-Coding RNAs against Viral Infection}

Plant viruses cause significant economic losses in a wide range of crops. Virus infections cause symptoms such as necrosis, yellowing, leaf spot, mosaic color, and abnormal 
growth in plants. These viruses could possess either DNA or RNA as their genetic material. However, DNA viruses are the less common agent of plant diseases and mostly the single or double-stranded RNA viruses infect plants by utilizing RNA-dependent RNA polymerase (RDRP) activity. An RNA virus usually replicates in the cytoplasm with few exceptions such as retroviruses and negative single-stranded RNA (ssRNA) viruses.

Generally, pathogen recognition activates a cascade of signaling pathways governing defense response. However, recently, the roles of lncRNAs involved in defense responses have been emerging. An expression analysis of lncRNAs indicated that several lncRNAs such as lincRNA and lncNATs were differentially regulated in response to the tomato yellow leaf curl virus (TYLCV) infection in TYLCV-resistant cultivar CLN2777 [36,62]. TYLCV belongs to the DNA Geminivirus containing a single-stranded circular DNA molecule in its genome. The lincRNAs such as slylnc0048, slylnc0049, slylnc0483, slylnc0531, and slyinc0934 were found to be upregulated and slylnc0475, slylnc0476, slylnc0673, and slylnc1052 were downregulated in an expression analysis, suggesting their role in defense response against viral infection. Later, the lncRNA SlLNR1 from tomato (Solanum lycopersicum L.) was reported to be involved in plant growth and leaf development. A viral small interfering RNA (vsRNA) derived from the intergenic region (IR) of TYLCV is almost perfectly complementary with long non-coding RNA, SlLNR1. The non-coding IR sequence of intergenic regions consists of 25 nucleotides, which are required for replication and transcription within the host cells. The vsRNA induces silencing of SlLNR1 in TYLCV-susceptible tomato cultivar by RNAi and its downregulation causes stunted plant growth and curled leaf phenotypes [36,78]. A deletion in the $25 \mathrm{nt}$ IR sequences has provided resistance to vsRNAdirected repression, as in the case of TYLCV-resistant cultivar CLN2777 (Figure 3). This is a good example of post-transcriptional gene silencing in which SlLNR1 is targeted by IR derived siRNA.

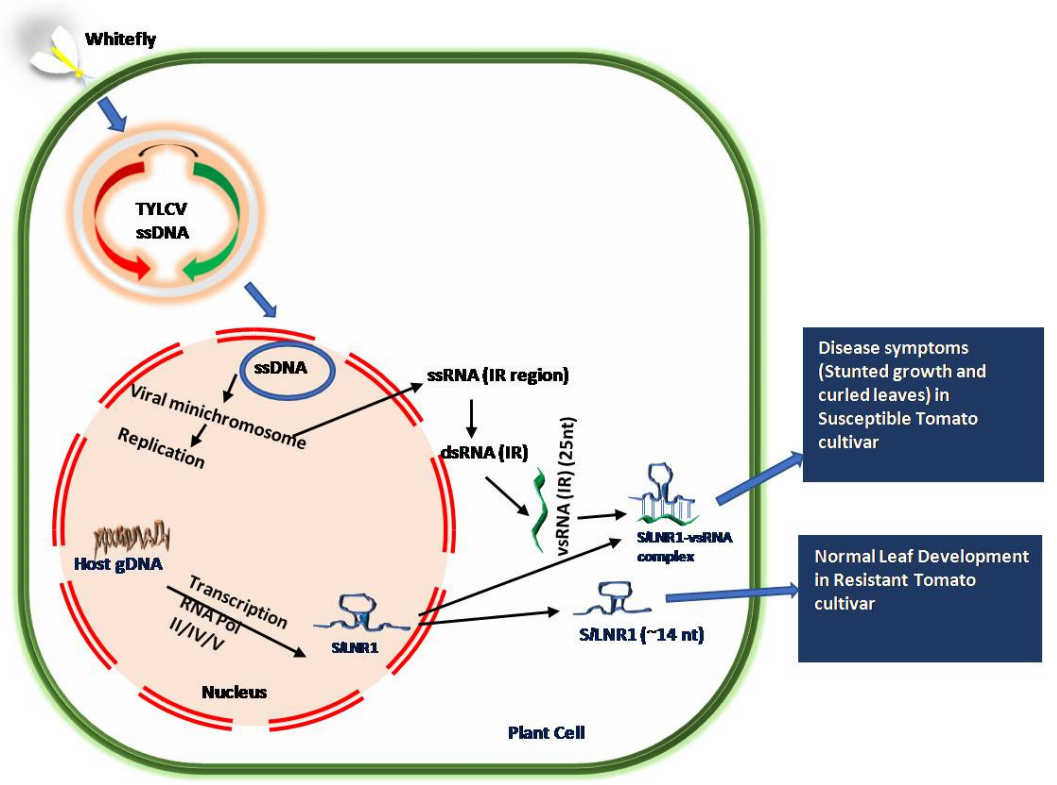

Figure 3. Mechanism of the pathogenesis of the TYLCV virus in susceptible and resistant tomato cultivar. Binding of vsRNA in susceptible cultivar leads to disease symptoms, while deletion in SlLNR1 sequence in resistant tomato cultivar shows no disease symptoms. The figure has been adapted and modified by permission from Springer Nature Customer Service Centre GmbH, Springer Nature, Journal of Plant Biochemistry and Biotechnology, 30, 684-697, 2021, Roles of long non-coding RNAs in plant virus interactions by Kumar, K and Chakraborty, S [36]. Copyright (C) 2021 by Springer Nature, License Number: 5237560546685.

Studies have predicted the possibility of a complex gene-regulating relationship between lncRNA and mRNA. Rice black-streaked dwarf virus (RBSDV) is a non-enveloped 
RNA virus transmitted through small brown planthopper. The transcriptomic profile of RBSDV-infected rice plants has revealed a total of 1342 differentially expressed (DE) mRNAs and 22 differentially expressed lncRNAs [36,79]. A co-expression network analysis of these DEmRNAs and DElncRNAs has shown a possible sign of the presence of a gene regulatory network in the plant-pathogen interaction pathways. An RBSDV infection results in the expression of many lncRNAs regulating the expression of several genes beneficial in plant defense mechanisms, as well as in viral pathogenesis. Genes beneficial to host plants in defense response include genes encoding for LRR domain-containing proteins, ubiquitinmediated proteasomal degradation proteins, and calmodulin-like proteins, as well as genes related to flavonoid biosynthesis. The genes beneficial in viral pathogenesis involve genes related to hormone signaling and biosynthesis. The molecular mechanisms of a very few lncRNAs have been understood in viral response until now. Therefore, in addition to the PTGS through siRNAs, some lncRNAs also act as endogenous target mimics (eTM) for miRNAs in plants. For instance, silencing of slylnc 0195 by viral-induced gene silencing (VIGS) has resulted in the accumulation of virus in slylnc0195-VIGS Nicotiana benthamiana plants showing miR166 as its putative targets and its functioning via miRNAs target mimics [36,62] and lncRNALNC_1497 which acts as miRNA mimics of MIR4995-p5_Iss19GC and regulates NAC gene (Cla010201) in cucumber green mottle mosaic virus (CGMMV) infection $[36,63]$. Moreover, detailed information regarding the role of lncRNAs and their mechanism in various viral pathogenesis has been described in a previous report [36].

\subsection{Long Non-Coding RNAs against Bacterial Infection}

In addition to fungi and viruses, bacteria are another major threat to plants, which causes yield loss by means of various diseases. The role of lncRNAs in bacterial disease resistance is still less explored as compared with other known pathogens. However, a few studies have demonstrated the involvement of lncRNAs in bacterial disease resistance [55-57]. Bacterial canker disease of kiwi fruit is caused by the Pseudomonas syringae pv. actinidiae (Psa) and shows variable symptoms such as dark brown spots on leaves and cankers on the stem. The kiwi fruit responds through a variety of immune processes against the Psa pathogen. The upregulation of lncRNAs and their interaction with various signaling and defense-related genes has been reported in Psa-infected kiwi fruit. The lncRNAs were predicted to provide immunity to plants by playing their roles in systematic acquired resistance (SAR), salicylic acid-mediated signaling pathway, and chitin catabolic processes [54]. Plants activate the diverse defense responses in turn of microbe signal detection through PRRs. These responses include the production of assorted antimicrobial compounds and PR proteins $[80,81]$. The PR group of proteins are important due to their antimicrobial activities [56]. Recently, Seo et al. identified a lncRNA named ELF18-INDUCED LONGNONCODING RNA1 (ELENA1) in the Arabidopsis thaliana. Overexpression of ELENA1 increased the degree of resistance against Pseudomonas syringae pv. tomato DC3000 by upregulating the PR1 proteins [55].

Xanthomonas oryzae pv. oryzae (Xoo) causes bacterial leaf blight disease of rice plants. It is considered to be the most harmful disease of rice, which is responsible for rice destruction throughout the world. Yu et al. (2020) carried out the strand-specific RNA sequencing of Xanthomonas oryzae pv. Oryzae (Xoo) infected leaves of rice at 2, 6, 12, and $24 \mathrm{~h}$ of postinoculation. In their work, they identified a total of 567 differential expressed lncRNAs. Further, these lncRNAs showed their interaction with a variety of stress-related mRNAs, which provided insight into their roles in plant defense pathways. The enhancer trap system approach was used to develop the mutant rice plants having overexpressed ALEX1 (a leaf expressed and Xoo-induced lncRNA 1). Jasmonic acid (JA) is an important phytohormone known to play a vital role in rice-Xoo interactions. The JA and salicylic acids are reported to enhance the various defense pathways by regulating the different PR proteins. ALEX1 was found to be responsible for the activation of the JA pathway. The participation of ALEX1 in JA signaling activation has been confirmed by various findings such as upregulation of JA interacting genes, root and shoot growth inhibition, and increased level of jasmonates 
in mutant rice plants [57]. Collectively, these findings show the connection of lncRNAs in bacterial disease resistance by mediating the various signaling pathways; however, the exact mechanism of action is still ambiguous and needs to be explored in future studies.

\section{Conclusions}

Rapid identification of novel lncRNAs and their functional characterization has become possible due to recent advances in high-throughput sequencing and computational biology. It has revealed the multifaceted regulatory function of lncRNAs in composite regulatory pathways, playing a vital role not just in plant immune response but also in several plant development processes, hormone signaling, and pathogenesis. Despite their known roles as miRNA and siRNA precursors, and miRNAs mimic, the specific role of lncRNAs in defense-related signaling pathways is yet to be deciphered. However, the specific role of some of the lncRNAs in different stresses has been identified in model plants such as Arabidopsis and tomato, using techniques such as RNAi and virus-induced gene silencing. The synteny relationship among crop plants and model plants can give a major boost to the functional characterization of novel lncRNAs of crop plants. In this review, we have summarized the mode of action and functions of lncRNAs related to some major biotic stresses. It is important to emphasize research about stress regulatory lncRNAs due to their significance in crop improvement programs. The molecular mechanisms regulating stress responses such as functional crosstalk among miRNA and lncRNAs are still unexplored and have significant importance in enhancing our understanding of stress tolerance. The ability of lncRNAs to mitigate regulatory and functional proteins at the transcriptional and post-transcriptional levels has flagged them as key players not only in the cellular and developmental processes but also in stress response. Therefore, we present lncRNAs as worthy candidates requiring attention in future research that will further strengthen our knowledge to overcome the global food crisis caused by pathogens.

Author Contributions: Conceptualization, S.K.U.; investigation, S.K.U. and Y.S.; resources, Y.S. and K.S.; data curation, Y.S., A.S. and M.; writing-original draft preparation, Y.S., A.S., S. and M.; writing-review and editing, Y.S., A.S., K.S. and S.K.U.; supervision, S.K.U. All authors have read and agreed to the published version of the manuscript.

Funding: We have not received any funding for this work.

Institutional Review Board Statement: Not applicable.

Informed Consent Statement: Not applicable.

Data Availability Statement: Not applicable.

Acknowledgments: The authors are grateful to Panjab University, Chandigarh for the facility. Y.S. and M. are thankful to U.G.C., and A.S. and S. are grateful to CSIR for their fellowships.

Conflicts of Interest: The authors declare no conflict of interest.

\section{References}

1. Budak, H.; Kaya, S.B.; Cagirici, H.B. Long Non-coding RNA in Plants in the Era of Reference Sequences. Front. Plant Sci. 2020, 11, 276. [CrossRef] [PubMed]

2. Urquiaga, M.C.O.; Thiebaut, F.; Hemerly, A.S.; Ferreira, P.C.G. From Trash to Luxury: The Potential Role of Plant LncRNA in DNA Methylation during Abiotic Stress. Front. Plant Sci. 2021, 11, 603246. [CrossRef]

3. Tyagi, S.; Sharma, A.; Upadhyay, S.K. Role of next-generation RNA-seq data in discovery and characterization of long non-coding RNA in plants. In Next Generation Plant Breeding; Intech Open: London, UK, 2018. [CrossRef]

4. Ponting, C.P.; Oliver, P.L.; Reik, W. Evolution and functions of long noncoding RNAs. Cell 2009, 136, 629-641. [CrossRef]

5. Wang, Y.; Fan, X.; Lin, F.; He, G.; Terzaghi, W.; Zhu, D.; Deng, X.W. Arabidopsis noncoding RNA mediates control of photomorphogenesis by red light. Proc. Natl. Acad. Sci. USA 2014, 111, 10359-10364. [CrossRef]

6. Fan, Y.; Yang, J.; Mathioni, S.M.; Yu, J.; Shen, J.; Yang, X.; Wang, L.; Zhang, Q.; Cai, Z.; Xu, C.; et al. PMS1T, producing Phased small-interfering RNAs, regulates photoperiod sensitive male sterility in rice. Proc. Natl. Acad. Sci. USA 2016, 113, 15144-15149. [CrossRef] [PubMed] 
7. Zhang, H.; Hu, W.; Hao, J.; Lv, S.; Wang, C.; Tong, W.; Wang, Y.; Wang, Y.; Liu, X.; Ji, W. Genome-wide identification and functional prediction of novel and fungi-responsive lincRNAs in Triticum aestivum. BMC Genom. 2016, 17, 238. [CrossRef] [PubMed]

8. Sun, X.; Zheng, H.; Li, J.; Liu, L.; Zhang, X.; Sui, N. Comparative transcriptome analysis reveals new lncRNAs responding to salt stress in sweet sorghum. Front. Bioeng. Biotechnol. 2020, 8, 331. [CrossRef]

9. Upadhyay, S.K. Long Noncoding RNAs in Plants: Roles in Development and Stress; Academic Press: Cambridge, MA, USA, 2021. [CrossRef]

10. Pachnis, V.; Belayew, A.; Tilghman, S.M. Locus unlinked to alpha-fetoprotein under the control of the murine raf and Rif genes. Proc. Natl. Acad. Sci. USA 1984, 81, 5523-5527. [CrossRef]

11. Zhang, H.; Guo, H.; Hu, W.; Ji, W. The Emerging Role of Long Non-Coding RNAs in Plant Defense against Fungal Stress. Int. J. Mol. Sci. 2020, 21, 2659. [CrossRef]

12. Dinger, M.E.; Pang, K.C.; Mercer, T.R.; Crowe, M.L.; Grimmond, S.M.; Mattick, J.S. NRED: A database of long noncoding RNA expression. Nucleic Acids Res. 2009, 37, D122-D126. [CrossRef]

13. Wierzbicki, A.T.; Haag, J.R.; Pikaard, C.S. Noncoding transcription by RNA polymerase Pol IVb/Pol V mediates transcriptional silencing of overlapping and adjacent genes. Cell 2008, 135, 635-648. [CrossRef]

14. Kung, J.T.; Colognori, D.; Lee, J.T. Long noncoding RNAs: Past, present, and future. Genetics 2013, 193, 651-669. [CrossRef]

15. Mattick, J.S.; Rinn, J.L. Discovery and annotation of long noncoding RNAs. Nat. Struct. Mol. Biol. 2015, 22, 5-7. [CrossRef] [PubMed]

16. Wu, H.; Yang, L.; Chen, L.L. The Diversity of Long Noncoding RNAs and Their Generation. Trends Genet. 2017, 33, 540-552. [CrossRef] [PubMed]

17. Wang, K.C.; Chang, H.Y. Molecular mechanisms of long noncoding RNAs. Mol. Cell 2011, 43, 904-914. [CrossRef] [PubMed]

18. Jin, J.; Liu, J.; Wang, H.; Wong, L.; Chua, N.-H. PLncDB: Plant long non-coding RNA database. Bioinformatics 2013, $29,1068-1071$. [CrossRef]

19. Wang, Y.; Wang, X.; Deng, W.; Fan, X.; Liu, T.-T.; He, G.; Chen, R.; Terzaghi, W.; Zhu, D.; Deng, X.W. Genomic features and regulatory roles of intermediate-sized non-coding RNAs in Arabidopsis. Mol. Plant 2014, 7, 514-527. [CrossRef]

20. Heo, J.B.; Sung, S. Vernalization-Mediated Epigenetic Silencing by a Long Intronic Noncoding RNA. Science 2011, 331, 76-79. [CrossRef]

21. Shin, J.-H.; Chekanova, J.A. Arabidopsis RRP6L1 and RRP6L2 function in FLOWERING LOCUS C silencing via regulation of antisense RNA synthesis. PLoS Genet. 2014, 10, e1004612. [CrossRef]

22. Van Dijk, E.L.; Chen, C.L.; d'Aubenton-Carafa, Y.; Gourvennec, S.; Kwapisz, M.; Roche, V.; Bertrand, C.; Silvain, M.; Legoix-Né, P.; Loeillet, S.; et al. XUTs are a class of Xrn1-sensitive antisense regulatory non-coding RNA in yeast. Nature 2011, 475, 114-117. [CrossRef] [PubMed]

23. Schulz, D.; Schwalb, B.; Kiesel, A.; Baejen, C.; Torkler, P.; Gagneur, J.; Soeding, J.; Cramer, P. Transcriptome surveillance by selective termination of noncoding RNA synthesis. Cell 2013, 155, 1075-1087. [CrossRef]

24. Fox, M.J.; Gao, H.; Smith-Kinnaman, W.R.; Liu, Y.; Mosley, A.L. The exosome component Rrp6 is required for RNA polymerase II termination at specific targets of the Nrd1-Nab3 pathway. PLoS Genet. 2015, 11, e1004999. [CrossRef]

25. Flynn, R.A.; Almada, A.E.; Zamudio, J.R.; Sharp, P.A. Antisense RNA polymerase II divergent transcripts are P-TEFb dependent and substrates for the RNA exosome. Proc. Natl. Acad. Sci. USA 2011, 108, 10460-10465. [CrossRef]

26. Hetzel, J.; Duttke, S.H.; Benner, C.; Chory, J. Nascent RNA sequencing reveals distinct features in plant transcription. Proc. Natl. Acad. Sci. USA 2016, 113, 12316-12321. [CrossRef] [PubMed]

27. Necsulea, A.; Soumillon, M.; Warnefors, M.; Liechti, A.; Daish, T.; Zeller, U.; Baker, J.C.; Grützner, F.; Kaessmann, H. The evolution of lncRNA repertoires and expression patterns in tetrapods. Nature 2014, 505, 635-640. [CrossRef] [PubMed]

28. Zhao, L.; Wang, J.; Li, Y.; Song, T.; Wu, Y.; Fang, S.; Bu, D.; Li, H.; Sun, L.; Pei, D.; et al. NONCODEV6: An updated database dedicated to long non-coding RNA annotation in both animals and plants. Nucleic Acids Res. 2021, 49, D165-D171. [CrossRef]

29. Bhatia, G.; Goyal, N.; Sharma, S.; Upadhyay, S.K.; Singh, K. Present Scenario of Long Non-Coding RNAs in Plants. Non-Coding RNA 2017, 3, 16. [CrossRef]

30. Yi, X.; Zhang, Z.; Ling, Y.; Xu, W.; Su, Z. PNRD: A plant non-coding RNA database. Nucleic Acids Res. 2015, 43, D982-D989. [CrossRef]

31. Paytuví Gallart, A.; Hermoso Pulido, A.; Anzar Martínez de Lagrán, I.; Sanseverino, W.; Aiese Cigliano, R. GREENC: A Wiki-based database of plant lncRNAs. Nucleic Acids Res. 2016, 4, D1161-D1166. [CrossRef]

32. Lamesch, P.; Berardini, T.Z.; Li, D.; Swarbreck, D.; Wilks, C.; Sasidharan, R.; Muller, R.; Dreher, K.; Alexander, D.L.; GarciaHernandez, M.; et al. The Arabidopsis Information Resource (TAIR): Improved gene annotation and new tools. Nucleic Acids Res. 2012, 40, D1202-D1210. [CrossRef] [PubMed]

33. Cheng, C.-Y.; Krishnakumar, V.; Chan, A.P.; Thibaud-Nissen, F.; Schobel, S.; Town, C.D. Araport11: A complete reannotation of the Arabidopsis thaliana reference genome. Plant J. 2017, 89, 789-804. [CrossRef] [PubMed]

34. Chen, D.; Yuan, C.; Zhang, J.; Zhang, Z.; Bai, L.; Meng, Y.; Chen, L.-L.; Chen, M. PlantNATsDB: A comprehensive database of plant natural antisense transcripts. Nucleic Acids Res. 2012, 40, D1187-D1193. [CrossRef] [PubMed]

35. Szcześniak, M.W.; Rosikiewicz, W.; Makałowska, I. CANTATAdb: A collection of plant long non-coding RNAs. Plant Cell Physiol. 2016, 57, e8. [CrossRef] 
36. Kumar, K.; Chakraborty, S. Roles of long non-coding RNAs in plant virus interactions. J. Plant Biochem. Biotechnol. 2021, 30, 684-697. [CrossRef]

37. Liu, J.; Jung, C.; Xu, J.; Wang, H.; Deng, S.; Bernad, L.; Arenas-Huertero, C.; Chua, N.H. Genome-wide analysis uncovers regulation of long intergenic noncoding RNAs in Arabidopsis. Plant Cell 2012, 24, 4333-4345. [CrossRef] [PubMed]

38. Sharma, S.; Taneja, M.; Tyagi, S.; Singh, K.; Upadhyay, S.K. Survey of high throughput RNA-seq data reveals potential roles for lncRNAs during development and stress response in bread wheat. Front. Plant Sci. 2017, 8, 1019. [CrossRef]

39. Zhang, Y.C.; Liao, J.Y.; Li, Z.Y.; Yu, Y.; Zhang, J.P.; Li, Q.F.; Qu, L.H.; Shu, W.S.; Chen, Y.Q. Genome-wide screening and functional analysis identify a large number of long noncoding RNAs involved in the sexual reproduction of rice. Genome Biol. 2014, 15, 512. [CrossRef]

40. Li, L.; Eichten, S.R.; Shimizu, R.; Petsch, K.; Yeh, C.T.; Wu, W.; Chettoor, A.M.; Givan, S.A.; Cole, R.A.; Fowler, J.E.; et al. Genome-wide discovery and characterization of maize long non-coding RNAs. Genome Biol. 2014, 15, R40. [CrossRef]

41. Wen, J.; Parker, B.J.; Weiller, G.F. In silico identification and characterization of mRNA-like noncoding transcripts in Medicagotruncatula. Silico Biol. 2007, 7, 485-505.

42. Bhatia, G.; Sharma, S.; Upadhyay, S.K.; Singh, K. Long Non-coding RNAs Coordinate Developmental Transitions and Other Key Biological Processes in Grapevine. Sci. Rep. 2019, 9, 3552. [CrossRef]

43. Datta, R.; Paul, S. Long non-coding RNAs: Fine-tuning the developmental responses in plants. J. Biosci. 2019, 44, 77. [CrossRef]

44. Shafiq, S.; Li, J.; Sun, Q. Functions of plants long non-coding RNAs. Biochim. Biophys. Acta (BBA)-Gene Regul. Mech. 2016, 1859, 155-162. [CrossRef]

45. Liu, F.; Marquardt, S.; Lister, C.; Swiezewski, S.; Dean, C. Targeted 3' processing of antisense transcripts triggers Arabidopsis FLC chromatin silencing. Science 2010, 327, 94-97. [CrossRef] [PubMed]

46. Sun, Q.; Csorba, T.; Skourti-Stathaki, K.; Proudfoot, N.J.; Dean, C. R-loop stabilization represses antisense transcription at the Arabidopsis FLC locus. Science 2013, 340, 619-621. [CrossRef]

47. Gultyaev, A.P.; Roussis, A. Identification of conserved secondary structures and expansion segments in enod40 RNAs reveals new enod40 homologues in plants. Nucleic Acids Res. 2007, 35, 3144-3152. [CrossRef]

48. Ariel, F.; Jegu, T.; Latrasse, D.; Romero-Barrios, N.; Christ, A.; Benhamed, M.; Crespi, M. Noncoding transcription by alternative RNA polymerases dynamically regulates an auxin-driven chromatin loop. Mol. Cell 2014, 55, 383-396. [CrossRef]

49. Kakar, K.; Zhang, H.; Scheres, B.; Dhonukshe, P. Retraction: CLASP-mediated cortical microtubule organization guides PIN polarization axis. Nature 2014, 508, 274. [CrossRef]

50. Franco-Zorrilla, J.M.; Valli, A.; Todesco, M.; Mateos, I.; Puga, M.I.; Rubio-Somoza, I.; Leyva, A.; Weigel, D.; García, J.A.; Paz-Ares, J. Target mimicry provides a new mechanism for regulation of microRNA activity. Nat. Genet. 2007, 39, 1033-1037. [CrossRef]

51. Jiao, Y.; Lau, O.S.; Deng, X.W. Light-regulated transcriptional networks in higher plants. Nat. Rev. Genet. 2007, 8, 217-230. [CrossRef] [PubMed]

52. Ding, J.; Lu, Q.; Ouyang, Y.; Mao, H.; Zhang, P.; Yao, J.; Xu, C.; Li, X.; Xiao, J.; Zhang, Q. A long noncoding RNA regulates photoperiod-sensitive male sterility, an essential component of hybrid rice. Proc. Natl. Acad. Sci. USA 2012, 109, 2654-2659. [CrossRef] [PubMed]

53. Zhou, H.; Liu, Q.; Li, J.; Jiang, D.; Zhou, L.; Wu, P.; Lu, S.; Li, F.; Zhu, L.; Liu, Z.; et al. Photoperiod- and thermo-sensitive genic male sterility in rice are caused by a point mutation in a novel noncoding RNA that produces a small RNA. Cell Res. 2012, 22, 649-660. [CrossRef] [PubMed]

54. Nejat, N.; Mantri, N. Emerging roles of long non-coding RNAs in plant response to biotic and abiotic stresses. Crit. Rev. Biotechnol. 2018, 38, 93-105. [CrossRef]

55. Seo, J.S.; Sun, H.-X.; Park, B.S.; Huang, C.-H.; Yeh, S.-D.; Jung, C.; Chua, N.-H. ELF18-INDUCED LONG-NONCODING RNA Associates with Mediator to Enhance Expression of Innate Immune Response Genes in Arabidopsis. Plant Cell 2017, 29, 1024-1038. [CrossRef]

56. Wang, Z.; Liu, Y.; Li, L.; Li, D.; Zhang, Q.; Guo, Y.; Wang, S.; Zhong, C.; Huang, H. Whole transcriptome sequencing of Pseudomonas syringae pv. actinidiae-infected kiwifruit plants reveals species-specific interaction between long non-coding RNA and coding genes. Sci. Rep. 2017, 7, 4910. [CrossRef]

57. Yu, Y.; Zhou, Y.F.; Feng, Y.Z.; He, H.; Lian, J.P.; Yang, Y.W.; Lei, M.Q.; Zhang, Y.C.; Chen, Y.Q. Transcriptional landscape of pathogen-responsive lncRNAs in rice unveils the role of ALEX1 in jasmonate pathway and disease resistance. Plant Biotechnol. J. 2020, 8, 679-690. [CrossRef]

58. Xin, M.; Wang, Y.; Yao, Y.; Song, N.; Hu, Z.; Qin, D.; Xie, C.; Peng, H.; Ni, Z.; Sun, Q. Identification and characterization of wheat long non-protein coding RNAs responsive to powdery mildew infection and heat stress by using microarray analysis and SBS sequencing. BMC Plant Biol. 2011, 11, 61. [CrossRef]

59. Joshi, R.K.; Megha, S.; Basu, U.; Rahman, M.H.; Kav, N.N. Genome Wide Identification and Functional Prediction of Long Non-Coding RNAs Responsive to Sclerotinia sclerotiorum Infection in Brassica napus. PLoS ONE 2016, 11, e0158784. [CrossRef]

60. Zhu, Q.H.; Stephen, S.; Taylor, J.; Helliwell, C.A.; Wang, M.B. Long noncoding RNAs responsive to Fusarium oxysporum infection in Arabidopsis thaliana. New Phytol. 2014, 201, 574-584. [CrossRef]

61. Zhang, H.; Chen, X.; Wang, C.; Xu, Z.; Wang, Y.; Liu, X.; Kang, Z.; Ji, W. Long non-coding genes implicated in response to stripe rust pathogen stress in wheat (Triticum aestivum L.). Mol. Biol. Rep. 2013, 40, 6245-6253. [CrossRef] [PubMed] 
62. Wang, J.; Yu, W.; Yang, Y.; Li, X.; Chen, T.; Liu, T.; Ma, N.; Yang, X.; Liu, R.; Zhang, B. Genome-wide analysis of tomato long non-coding RNAs and identification as endogenous target mimic for microRNA in response to TYLCV infection. Sci. Rep. 2015, 5, 16946. [CrossRef] [PubMed]

63. Sun, Y.; Zhang, H.; Fan, M.; He, Y.; Guo, P. Genome-wide identification of long non-coding RNAs and circular RNAs reveal their ceRNA networks in response to cucumber green mottle mosaic virus infection in watermelon. Arch. Virol. 2020, 165, 1177-1190. [CrossRef]

64. Bhogireddy, S.; Mangrauthia, S.K.; Kumar, R.; Pandey, A.K.; Singh, S.; Jain, A.; Budak, H.; Varshney, R.K.; Kudapa, H. Regulatory non-coding RNAs: A new frontier in regulation of plant biology. Funct. Integr. Genom. 2021, 21, 313-330. [CrossRef]

65. Cui, J.; Luan, Y.; Jiang, N.; Ba, H.; Meng, J. Comparative transcriptome analysis between resistant and susceptible tomato allows the identification of lncRNA16397 conferring resistance to Phytophthora infestans by co-expressing glutaredoxin. Plant J. 2017, 89, 577-589. [CrossRef]

66. Rouhier, N.; Lemaire, S.D.; Jacquot, J.P. The role of glutathione in photosynthetic organisms: Emerging functions for glutaredoxins and glutathionylation. Annu. Rev. Plant Biol. 2008, 59, 143-166. [CrossRef]

67. Bhatia, G.; Upadhyay, S.K.; Upadhyay, A.; Singh, K. Investigation of long non-coding RNAs as regulatory players of grapevine response to powdery and downy mildew infection. BMC Plant Biol. 2021, 21, 265. [CrossRef] [PubMed]

68. Bhatia, G.; Upadhyay, S.K.; Singh, K. Vitis vinifera (Grapevine) lncRNAs are potential regulators of response to necrotrophic fungus, Botrytis cinerea infection. Physiol. Mol. Plant Pathol. 2020, 112, 101553. [CrossRef]

69. Liu, W.; Liu, J.; Ning, Y.; Ding, B.; Wang, X.; Wang, Z.; Wang, G.L. Recent progress in understanding PAMP- and effector-triggered immunity against the rice blast fungus Magnaporthe oryzae. Mol. Plant 2013, 6, 605-620. [CrossRef] [PubMed]

70. Dodds, P.N.; Rathjen, J.P. Plant immunity: Towards an integrated view of plant-pathogen interactions. Nat. Rev. Genet. 2010, 11, 539-548. [CrossRef]

71. Maekawa, T.; Kufer, T.A.; Schulze-Lefert, P. NLR functions in plant and animal immune systems: So far and yet so close. Nat. Immunol. 2011, 12, 817-826. [CrossRef]

72. Gassmann, W.; Bhattacharjee, S. Effector-triggered immunity signaling: From gene-for-gene pathways to protein- protein interaction networks. Mol. Plant-Microbe Interact. 2012, 25, 862-868. [CrossRef]

73. Boller, T.; Felix, G. A renaissance of elicitors: Perception of microbe-associated molecular patterns and danger signals by pattern-recognition receptors. Annu. Rev. Plant Biol. 2009, 60, 379-406. [CrossRef]

74. de Jonge, R.; van Esse, H.P.; Maruthachalam, K.; Bolton, M.D.; Santhanam, P.; Saber, M.K.; Zhang, Z.; Usami, T.; Lievens, B.; Subbarao, K.V.; et al. Tomato immune receptor Ve1 recognizes effector of multiple fungal pathogens uncovered by genome and RNA sequencing. Proc. Natl Acad. Sci. USA 2012, 109, 5110-5115. [CrossRef]

75. Yang, S.; Li, J.; Zhang, X.; Zhang, Q.; Huang, J.; Chen, J.Q.; Hartl, D.L.; Tian, D. Rapidly evolving R genes in diverse grass species confer resistance to rice blast disease. Proc. Natl Acad. Sci. USA 2013, 110, 18572-18577. [CrossRef]

76. Liu, W.; Liu, J.; Triplett, L.; Leach, J.E.; Wang, G.L. Novel insights into rice innate immunity against bacterial and fungal pathogens. Annu. Rev. Phytopathol. 2014, 52, 213-241. [CrossRef] [PubMed]

77. Jiang, L.; Chen, Y.; Luo, L.; Peck, S.C. Central roles and regulatory mechanisms of dual-specificity MAPK phosphatases in developmental and stress signaling. Front. Plant Sci. 2018, 9, 1697. [CrossRef] [PubMed]

78. Yang, Y.; Liu, T.; Shen, D.; Wang, J.; Ling, X.; Hu, Z.; Chen, T.; Hu, J.; Huang, J.; Yu, W.; et al. Tomato yellow leaf curl virus intergenic siRNAs target a host long noncoding RNA to modulate disease symptoms. PLoS Pathog. 2019, 15, e1007534. [CrossRef] [PubMed]

79. Zhang, T.; Liang, Q.; Li, C.; Fu, S.; Kundu, J.K.; Zhou, X.; Wu, J. Transcriptome Analysis of Rice Reveals the lncRNA-mRNA Regulatory Network in Response to Rice Black-Streaked Dwarf Virus Infection. Viruses 2020, 12, 951. [CrossRef]

80. Van Loon, L.C.; Rep, M.; Pieterse, C.M. Significance of inducible defense-related proteins in infected plants. Annu. Rev.Phytopathol. 2006, 44, 135-162. [CrossRef] [PubMed]

81. Bednarek, P. Chemical warfare or modulators of defence responses-The function of secondary metabolites in plant immunity. Curr. Opin. Plant Biol. 2012, 15, 407-414. [CrossRef] [PubMed] 